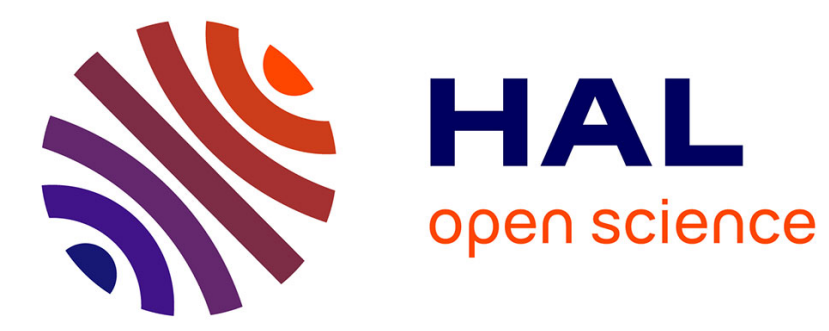

\title{
Review symposium: The left-Herderian ontology of multiculturalism
}

\author{
Andreas Wimmer
}

\section{To cite this version:}

Andreas Wimmer. Review symposium: The left-Herderian ontology of multiculturalism. Ethnicities, 2008, 8 (2), pp.254-260. 10.1177/14687968080080020102 . hal-00571895

\section{HAL Id: hal-00571895 \\ https://hal.science/hal-00571895}

Submitted on 1 Mar 2011

HAL is a multi-disciplinary open access archive for the deposit and dissemination of scientific research documents, whether they are published or not. The documents may come from teaching and research institutions in France or abroad, or from public or private research centers.
L'archive ouverte pluridisciplinaire HAL, est destinée au dépôt et à la diffusion de documents scientifiques de niveau recherche, publiés ou non, émanant des établissements d'enseignement et de recherche français ou étrangers, des laboratoires publics ou privés. 
Kymlicka, Will (1995) Multicultural Citizenship: A Liberal Theory of Minority Rights. Oxford: Oxford University Press.

Kymlicka, Will (1998) Finding Our Way: Rethinking Ethnocultural Relations in Canada. Oxford: Oxford University Press.

Kymlicka, Will (2007) Multicultural Odysseys. The New International Politics of Diversity. Oxford: Oxford University Press.

Kymlicka, Will and Baogang He (eds) (2005) Multiculturalism in Asia. Oxford: Oxford University Press.

Kymlicka, Will and Magda Opalski (eds) (2002) Can Liberal Pluralism be Exported? Western Political Theory and Ethnic Relations in Eastern Europe. Oxford: Oxford University Press.

RAINER BAUBÖCK is Professor of social and political theory at the European University Institute, Italy. Address: European University Institute,via dei Roccettini, 9, I-50014 San Domenico di Fiesole (FI), Italy. [email: rainer.baubock@eui.eu]

\section{The left-Herderian ontology of multiculturalism}

\section{ANDREAS WIMMER}

The University of California, Los Angeles

Will Kymlicka's new book moves away from the normative tradition of reasoning, to which his earlier work has made well known and widely respected contributions, towards a more empirically oriented perspective informed by political science and political sociology. The book describes the major historical events and organizational channels through which liberal multiculturalism has come to influence major international policymaking bodies, what the experiences with putting multiculturalism into practice have been in North American and Europe, and why the global spread of multiculturalism has come to a halt before having had any impact on the reality of ethnic exclusion in Africa, Asia and the Middle East.

Why has the multicultural revolution stalled? Kymlicka's answer is based on a thorough review of the empirical literature and stands out for its nuanced and balanced nature. But the author seems to shy away from drawing the full consequences of his own analysis as. The disjuncture between analysis and conclusion emerges, I will argue because the book has 
not managed to overcome the ontology of multicultural philosophy, and to adopt a more empirically and analytically oriented view on the relation between ethnicity and politics. It has, if you will, stopped halfway on the road from normative theory to political analysis.

\section{DISJUNCTURE BETWEEN EMPIRICAL ANALYSIS AND POLICY CONCLUSIONS}

Will Kymlicka demonstrates that liberal multiculturalism has emerged under the following five conditions and argues that these also need to be fulfilled in order for other states and societies to adopt liberal multiculturalism in the future. First, only in established democracies will excluded minorities find the political space to articulate their demands and avoid being silenced and persecuted by hostile governments. Second, basic individual human rights need to be guaranteed and effectively enforced such that majorities can feel secure enough to grant collective rights to minorities without fearing that they will be oppressed in those regions and provinces where minorities will take over political power once granted territorial autonomy.

Third, liberal multiculturalism makes sense only where there is a clear opposition between a dominant ethnic group historically in control of the state and a minority that has been excluded from power. States controlled by minorities rather than majorities or governed by a multiplicity of smaller groups are less likely to develop and adopt liberal multiculturalism. Fourth, and perhaps most importantly, only where states and dominant majorities do not have to fear that granting minority rights will empower irredentist minorities supported by a hostile neighboring state will they be prepared to grant minority rights and overcome their security fears. Finally, where the minority rights regime, as developed by international organizations as well as western policy circles and governments, is perceived as a neo-colonial imposition designed to weaken states that have shaken off the yoke of colonial domination only recently, minority rights are unlikely to be embraced voluntarily and effectively.

The policy recommendations that the author offers throughout his book, however, are strangely out of tune with this analysis. He argues not for less, but for more liberal multiculturalism, irrespective of whether or not the above conditions are met. He pleads for a more consistent approach that would implement the full array of liberal multiculturalist policies, thus overcoming what he describes as a piecemeal and contradictory policy adopted by the international community.

More specifically, he deplores that the European Union (EU) has given up on pushing for the territorial autonomy of Eastern European minorities in the face of stiff resistance from governments; he argues that instead of 
retreating to under-specified general rights for all types of ethnic minorities, Europe should develop specific rights for national minorities and immigrants; he criticizes the pragmatic conflict-prevention approach (e.g. of the OSCE) for the inconsistent, case-specific definition of what constitutes a satisfactory level of minority political participation and argues instead to force governments of conflict-torn societies to accept a full array of constitutionally enshrined minority rights; he takes the UN to task for not having developed a legal framework for national minorities and and for focusing exclusively on indigenous peoples.

The reader wonders: if liberal multiculturalism only makes sense in demographic and political constellations where a historically dominant majority has oppressed minorities, why recommend it to countries where minorities have oppressed majorities, as in Burundi or Syria, or where, as in Tanzania or Zaire, it does not make sense at all to talk of minorities and majorities? If a firm human rights regime is necessary to alleviate fears of illiberal minority rule, why demand minority rights for countries that are not able to guarantee even minimal habeas corpus rights? If secure state borders and friendly neighboring states are needed to avoid the very real possibility of irredentism and secessionism, why ask for multicultural rights for the Caucasus or the Balkans where borders are in flux and neighbors hostile to each other?

Will Kymlicka does discuss, in the final pages of the book, a more realistic approach: that of sequencing the introduction of rights and demand minority rights only when human rights and democratic participation have been effectively institutionalized. This conclusion is fully compatible with his own analysis. But the idea of sequencing appears as an afterthought. In the main body of the book, Kymlicka asks for a deepening, broadening and worldwide generalization of minority rights now, irrespective of whether or not other rights are already guaranteed. And when sequencing is finally mentioned in the concluding chapter, he immediately tracks back, pointing out that solid knowledge about the proper sequence is lacking and hinting at cases such as post-Franco Spain where all rights were successfully introduced at the same time. Overall, then, the book reads like a defense of the initial argument, formulated some time ago, that spreading liberal multiculturalism across the globe and making it a principle of international law parallel to human rights is not only morally just, but also politically wise and feasible.

\section{THE FALLACIES OF A LEFT-HERDERIAN ONTOLOGY}

This inconsistency between analysis and conclusion derives, I believe, from the specific ontology that underlies the philosophy of multiculturalism developed by Will Kymlicka and others and that continues to provide the 
framework for this new book. What I mean by ontology are certain implicit assumptions about the basic building blocks and causal forces at work in society. Four such assumptions are crucial for what one could call the leftHerderian ontology of liberal multiculturalism.

First, the world is made up of states that guarantee or withhold rights to citizens and groups of citizens. Second, these state-bound societies are composed of ethnic groups.

Third, the majority group has dominated minorities and thus violated the basic cultural and political rights of the latter. Fourth, it is such violation of minority rights that produces conflict, while, conversely, the granting of such rights reduces conflicts.

Given these assumptions, globalizing multicultural policies is indeed the order of the day, despite all the difficulties that this project encounters. It is both morally preferable to continued ethnic exclusion and politically wise, because in the long run only multicultural rights can guarantee political peace. These conclusions are directly derived from the Herderian ontology and thus shielded from the insights of the author's own comparative political analysis.

Once we abandon this ontology and instead look at the real-world empirical constellations that we find across the globe, it becomes obvious how problematic these four assumptions are highly problematic. First, not all societies are governed by states that are capable of granting rights, as the recently burgeoning literature on 'failed states' shows. But even before such states became the concern of western governments fighting a 'global war on terror', there were large parts of the world that were not governed by strong centralized territorial states and where politics therefore was not about who gets which rights, but rather about who controls which parts of the territory and population.

The second assumption according to which societies are composed of ethnic groups is equally problematic, as Brubaker (2004) and many others before him have shown. The left-Herderian ontology does not distinguish between what political leaders say about the relevance and pervasiveness of ethnicity on the one hand, and the everyday lived experience of members of an ethnic category on the other hand. In other words, there is no space for considering and understanding the politics of ethnic representation. Thus, situations where 'minority representatives' indeed represent the lived aspirations, cultural idioms and political projects of a large majority of that minority cannot be distinguished from a situation where such leaders stand for little other than their own political ambition, which might be openly rejected by, the very 'people' these leaders claim to represent.

Third, in many societies, the main lines of political exclusion and struggle follow the contours of class, region or clientelistic factions, all of which can cross-cut ethnic categories. Not all politics is necessarily and everywhere 
about ethnicity and not all ethnicity is politically relevant. I am involved in a new research effort to create a database on ethnic power relations in all countries of the world after 1945, in the hope of improving upon the widely used Minorities at Risk dataset produced by Ted Gurr (cf. Wimmer et al., 2007). In 18 percent of country-years in this dataset, ethnicity is not politically relevant at all. For an additional 48 percent, ethnicity is politically relevant but the situation cannot be grasped by the majoritydominates-minority scheme either because the dominant group(s) form a demographic minority or because power is shared among more than one ethnically defined elite. Thus, the ontology of multiculturalism is at odds with approximately two thirds of the post-war world of independent states.

Fourth, the left-Herderian ontology also obscures rather than illuminates the processes that link ethnic politics to conflict. Ethnic conflicts often are not so much about rights that have been denied to ethnic minorities, but of making such types of demands and rights legitimate. More precisely, they are the consequence of tying rights to the ethnic or national background of individuals, a principle first introduced by the modern nation state. The diffusion of this institutional principle across the globe (e.g. into the realms of the former Soviet empire) opens up the question of who is member of a nation and therefore should be granted political participation, equality before the law etc. The answer is sought in a bloody history during which empires crumble, multiethnic states break apart and new nation states emerge, borders shift over people, and people are forced over borders. These conflicts and wars are the consequence of tying rights to ethnicity and nationhood where they were previously dissociated from each other (for empirical support of this hypothesis, see Wimmer and Min 2006). According to the left-Herderian ontology, however, rights are always and in principle a matter of ethnicity. The violent consequences of establishing this link in the first place therefore vanish from sight. This blind spot is illustrated in Kymlicka's analysis of the wars in the former Yugoslavia, which he attributes to a 'lack of minority rights'. Few regional experts would disagree, however, that the conflicts escalated when nationalist politicians started to advance competing and incompatible claims to rights and resources for their own ethnic constituencies.

How exactly linking rights to ethnicity and nationhood leads to conflict varies a great deal (cf. Wimmer, 2002: Ch. 4). More often than not, the political dynamic does not fit the 'lack of minority rights leads to conflict' scheme that the multicultural ontology implies. Sometimes it is long-oppressed majorities who mobilize against minorities on which colonial indirect rule relied, as Will Kymlicka himself notes; sometimes it is the elites of formerly independent states or regions (not long 'oppressed minorities') who fight against incorporation into a new state, as the Shan principalities of Burma; sometimes it is dominant, and not oppressed minorities who fight to secede 
from majorities rather than share resources with them and accept power sharing, as in Biafra; sometimes, various regional elites (none of them representing an 'oppressed minority') of a disintegrating empire pursue competing nationalist state-building projects, as in the former Soviet Union; sometimes the competition between clientelist power networks, organized along ethnic lines, escalates into violence (as between Inkatha and the African National Congress (ANC)); sometimes it is indeed, as the multiculturalist ontology foresees, minorities that fight for cultural and political rights long withheld from them by dominant majorities, as in Northern Ireland. Such is the case in roughly one fourth of all armed ethnic conflicts of the post-war world, according to our dataset, and in one seventh of all armed conflicts.

In summary, the left-Herderian ontology of multiculturalism corresponds to a rather specific, and empirically quite rare case of ethno-political constellations. Sometimes, there is no state to guarantee rights, neither multicultural nor others; in other cases, politics is not about ethnicity, but class, clientelistic competition, regional hegemony or political ideology; when, politics is primarily about ethnicity, it is not always the violation of the rights of minorities that leads to conflict, but elite competition for control of that state or the perpetuation of minority dominance through violence, and so forth.

Once the multiculturalist ontology is abandoned for a more realistic and differentiated view of how ethnicity relates to politics, we might want to rethink the policy conclusions that we should draw from past experience with the globalization of multiculturalism. If we want to achieve the goals of liberal multiculturalism, namely to reduce political domination, cultural oppression and economic discrimination along ethnic lines, we might have to abandon the idea of a global legal regime that fits all sizes, and instead proceed along a variety of different paths in different regions and countries. The toolbox, in other words, has to be opened and other ways to combat ethnic exclusion considered.

A non-ethnic, inclusive civil nationalism, perhaps of the rainbownationalism variant developed by some Carribean states (Patterson, 1975), might work very well for some countries in order to eliminate ethnic power hierarchies over time. A non-ethnic federal system without minority rights has helped Switzerland to avoid ethnocracy (Wimmer 2002: Ch. 8), but has not helped in overcoming ethnic discrimination when introduced in Bolivia. An ethnic federalism such as advocated by Will Kymlicka does not work in Nigeria and Ethiopia, but has produced benign results in India and Canada. A focus on anti-discrimination, including political discrimination, has helped to address ethnoracial inequalities in the USA, but it might produce perverse effects in Brazil (cf. the discussion in Telles, 2004).

Ethnic group rights therefore should not be understood on the same 
level of universality as human rights. The conditions under which they work are much more specific, as Will Kymlicka himslef shows in this remarkable book. The conclusion therefore has to be that eliminating ethnic discrimination must proceed on a variety of different tracks, each adapted to the specific context (cf. also Wimmer 2004). This certainly produces inconsistencies across countries and groups that a systematically minded philosopher or a global law maker might deplore. But if abandoning the project of globalizing multiculturalism is the prize for a more realistic prospect of achieving its goals, who would not be willing to pay it?

\section{References}

Brubaker, Rogers (2004) Ethnicity without Groups. Cambridge, MA: Harvard University Press.

Patterson, Orlando (1975) 'Context and Choice in Ethnic Allegiance: A Theoretical Framework and Caribbean Case Study', in Nathan Glazer and Daniel Patrick Moynihan (eds) Ethnicity: Theory and Experience, pp. 305-49. Cambridge, MA: Harvard University Press.

Telles, Edward E. (2004) Race in Another America: The Significance of Skin Color in Brazil. Princeton, NJ: Princeton University Press.

Wimmer, Andreas (2002) Nationalist Exclusion and Ethnic Conflicts. Shadows of Modernity. Cambridge, MA: Cambridge University Press.

Wimmer, Andreas (2004) 'Toward a New Realism', in Andreas Wimmer, Donald Horowitz, Richard Goldstone, Ulrike Joras and Conrad Schetter (eds) Facing Ethnic Conflict. Toward a New Realism, pp 1-12. Lanham, MD: Rowman \& Littlefield.

Wimmer, Andreas, and Brian Min (2006) 'From Empire to Nation-state: Explaining Wars in the Modern World, 1816-2001', American Sociological Review 71: 867-97.

Wimmer, Andreas, Lars-Erik Cederman and Brian Min (2007) 'Ethnic Politics and Violent Conflict, 1941-2005: A Configurational Approach', unpublished manuscript, Department of Sociology, UCLA, Los Angeles, CA.

ANDREAS WIMMER is Professor of Sociology in the Department of Sociology at The University of California, Los Angeles. Address: Department of Sociology, The University of California, Los Angeles, 264 Haines Hall, Box 951551, Los Angeles, CA 90095-1551, USA. [email: awimmer@ soc.ucla.edu] 